\title{
Germination and Inactivation of Alicyclobacillus acidoterrestris Spores Induced by Moderate Hydrostatic Pressure
}

\author{
BARBARA SOKOŁOWSKA ${ }^{1 *}$, SYLWIA SKĄPSKA ${ }^{1}$, MONIKA FONBERG-BROCZEK $^{2}$, JOLANTA NIEZGODA ${ }^{1}$, \\ IZABELA PORĘBSKA ${ }^{1}$, AGNIESZKA DEKOWSKA ${ }^{1}$ and SYLWESTER J. RZOSKA ${ }^{2}$ \\ ${ }^{1}$ Department of Fruit and Vegetable Product Technology, Prof. Wacław Dąbrowski Institute of Agricultural \\ and Food Biotechnology, Warsaw, Poland \\ ${ }^{2}$ Laboratory of Biomaterials, Institute of High Pressure Physics of the Polish Academy of Sciences, Warsaw, Poland
}

Submitted 22 June 2014, revised 21 October 2014, accepted 25 March 2015

\begin{abstract}
Given the importance of spoilage caused by Alicyclobacillus acidoterrestris for the fruit juice industry, the objective of this work was to study the germination and inactivation of A. acidoterrestris spores induced by moderate hydrostatic pressure. Hydrostatic pressure treatment can induce the germination and inactivation of A. acidoterrestris spores. At low $\mathrm{pH}$, spore germination of up to 3.59-3.75 log and inactivation of $1.85-2.04 \log$ was observed in a low pressure window (200-300 MPa) applied at $50^{\circ} \mathrm{C}$ for $20 \mathrm{~min}$. Neutral $\mathrm{pH}$ suppressed inactivation, the number of spores inactivated at $\mathrm{pH} 7.0$ was only $0.24-1.06 \mathrm{log}$. The pressurization temperature significantly affected spore germination and inactivation. The degree of germination in apple juice after pressurization for $30 \mathrm{~min}$ with $200 \mathrm{MPa}$ at $20^{\circ} \mathrm{C}$ was $2.04 \log$, with only $0.61 \mathrm{log}$ of spores being inactivated, while at $70^{\circ} \mathrm{C}$ spore germination was $5.94 \mathrm{log}$ and inactivation $4.72 \mathrm{log}$. This temperature strongly stimulated germination and inactivation under higher $(500 \mathrm{MPa})$ than lower $(200 \mathrm{MPa})$ pressure. When the oscillatory mode was used, the degree of germination and inactivation was slightly higher than at continuous mode. The degree of germination and inactivation was inversely proportional to the soluble solids content and was lowest in concentrated apple juice.
\end{abstract}

Ke y w o r d s: Alicyclobacillus acidoterrestris, germination, high hydrostatic pressure, inactivation spores

\section{Introduction}

Alicyclobacillus acidoterrestris, thermoacidophilic and spore-forming bacteria may cause spoilage of pasteurized juices and beverages, producing compounds associated with a disinfectant-like odour: guaiacol, 2,6-dibromophenol, 2,6-dichlorophenol (Baumgart et al., 1997; Borlinghaus and Engel, 1997, Pettipher et al., 1997; Orr et al., 2000; Jensen and Whitfield, 2003; Gocmen et al., 2005; Niwa, 2005; Danyluk et al., 2011).

These bacteria have been isolated from orchard soil (Eguchi et al., 2001; Goto et al., 2008; Groenewald et al., 2008; Wang etal., 2010), fruits (Eguchi et al., 2001; Parish and Goodrich, 2005), juice production environment (Eguchi et al., 2001; Steyn et al., 2011, Zhang et al., 2013) and from many final products-juices and juice concentrates, all over the world (Cerny et al., 1984; Splitstoesser et al., 1994; Baumgart et al., 1997; Pettipher et al., 1997; Eguchi et al., 2001; Durak et al., 2010; McKnight et al., 2010; Danyluk et al., 2011; Oteiza et al., 2011).

The presence of this new type of spoilage bacterium in aseptically packaged apple juice was first reported in 1984 (Cerny et al., 1984) and since then A. acidoterrestris has been recognized as a significant spoilage organism in the fruit juice industry (Silva et al., 2000).

A. acidoterrestris strains show the ability to germinate and grow at a pH range of from 2.0 to 6.0 at a temperature of $20-55^{\circ} \mathrm{C}$, with an optimum range of 42-53 ${ }^{\circ} \mathrm{C}$ (Baumgart et al., 1997; Deinhard et al., 1987; Sokołowska et al., 2010). A. acidoterrestris contains $\omega$-cyclohexyl fatty acids in its cellular membrane composition. These ring structures are of special physiological importance for cells at a high growth temperature and low pH (Kirschke and Poralla, 1990).

A. acidoterrestris spores show extremely high thermal resistance depending on the kind of juice, its soluble solids content and $\mathrm{pH}$. The values of $\mathrm{D}_{95}$ (time in minutes, during which the number of living cells decrease by $90 \%$, at $95^{\circ} \mathrm{C}$ ) in various juices that can be found in the literature were 1.85-15.1 min (Splittstoesser et al., 1994; Baumgart et al., 1997; Komitopolou et al., 1999; Silva et al., 1999; Bahceci and Acar, 2007; Sokołowska et al., 2008; Bevilacqua and Corbo, 2011). The standard pasteurization process using temperatures

* Corresponding author: B. Sokołowska, Department of Fruit and Vegetable Product Technology, Prof. Wacław Dąbrowski Institute of Agricultural and Food Biotechnology, Warsaw, Poland; e-mail: sokolowska@ibprs.pl 
of $85-95^{\circ} \mathrm{C}$, which is aimed at destroying vegetative pathogens, is therefore ineffective against these bacteria spores (Splitstoesser et al., 1994; Baumgart et al., 1997; Silva et al., 2000).

Using a higher temperature can negatively affect the nutritious and sensory quality of the juices, therefore there are attempts to use hydrostatic pressure (HP) as a non-thermal spore-inactivating process.

A few studies report $A$. acidoterrestris vegetative cell and spore inactivation by HP (Lee et al., 2002; Alpas et al., 2003; Ardia, 2004: Lee et al., 2006; Vercammen et al., 2012; Silva et al., 2012; Skąpska et al., 2012, Sokołowska et al., 2012, Sokołowska et al., 2013). A. acidoterrestris vegetative cells were killed by $\mathrm{HP}$ when $350 \mathrm{MPa}$ at $50^{\circ} \mathrm{C}$ was used. More than a $4 \log$ reduction was achieved in BAM broth (Bacillus acidocaldarius medium), orange, apple and tomato juices after $20 \mathrm{~min}$ pressurization (Alpas et al., 2003).

It was also shown that the effect of $A$. acidoterrestris spore inactivation in apple juice, using pressure ranging from 207 to $621 \mathrm{MPa}$ (up to $10 \mathrm{~min}$ ), was strongly dependent on the process temperature: at $22^{\circ} \mathrm{C}$ no reduction was achieved, at $45^{\circ} \mathrm{C}$ a max. $3.5 \log$ reduction occurred and at $70^{\circ} \mathrm{C}$ and at $90^{\circ} \mathrm{C}$, complete $(>5.5 \mathrm{log})$ reduction was observed after $5 \mathrm{~min}$ treatment, irrespective of the pressure used (Lee et al., 2002). In accordance with these results are those of Ardia (2004).

Previously a study by Skąpska et al. (2012), showed large differences in sensitivity to HP between the spores of eight wild A.acidoterrestris strains. The reduction in the spore number in apple juice after treating at $300 \mathrm{MPa}$ for $10 \mathrm{~min}$ was $1.3-3.5 \mathrm{log}$, depending on the strain. Increasing the pressure to $500 \mathrm{MPa}$ did not result in a significantly more efficient pasteurization process. The use of oscillatory high pressure has been proven to be more effective. The greatest reduction in spores of the two most resistant to HP A. acidoterrestris strains (TO-29/4/02 and TO-117/02) was 2.4 and $3.1 \log \mathrm{cfu} / \mathrm{ml}$ when $300 \mathrm{MPa}$ in six five-min cycles at $50^{\circ} \mathrm{C}$ were applied. Subsequent research (Sokołowska et al., 2012) has shown that lower pressure of $200 \mathrm{MPa}$ at $50^{\circ} \mathrm{C}$, applied both in a continuous and oscillatory mode, produced an even better effect. In these conditions, a reduction of $1.5 \mathrm{log}$ in the A.acidoterrestris (TO-29/4/02 strains) spore count in apple juice was obtained after $10 \mathrm{~min}$ of continuous pressurization. After six five-min cycles a reduction of $5.0 \mathrm{log}$ was achieved.

A recent study carried out using orange juice (Silva et al., 2012), showed an approximate $2 \log$ reduction in A. acidoterrestris spores after processing with $200 \mathrm{MPa}$ at $65^{\circ} \mathrm{C}$ for $10 \mathrm{~min}$, slightly better results $(\sim 2.5 \mathrm{log})$ were achieved when the pressure was increased to $600 \mathrm{MPa}$.

Only one article concerning the germination of A. acidoterrestris spores induced by HP was found (Vercammen et al., 2012). This experiment, carried out for $10 \mathrm{~min}$ with a pressure of $100-600 \mathrm{MPa}$, in buffers at $\mathrm{pH} 4.0,5.0$ and 7.0 and a temperature of $40^{\circ} \mathrm{C}$, showed no significant spore inactivation, although spore germination of up to about $2 \log$ was observed in a low pressure window (100-300 MPa). When spores were treated in tomato sauce with $\mathrm{pH} 4.2$ and 5.0 with $100-600 \mathrm{MPa}$ at 25,40 and $60^{\circ} \mathrm{C}$ for $10 \mathrm{~min}$, the germination level was generally higher than in buffers. HP treatment conducted at $60^{\circ} \mathrm{C}$ resulted in the inactivation of most of the germinated spores.

The inactivation of $A$. acidoterrestris spores under high pressure was shown to be suppressed by a high soluble solids content in apple juice concentrates (Lee et al., 2006; Sokołowska et al., 2013). No information about the germination of these spores in concentrated juices was found.

Depending on the temperature and level of pressure applied, bacterial endospores pass through different physiological pathways, which could induce spore germination or their subsequent inactivation during treatment. Moderate hydrostatic pressure induces spore germination by triggering the spores' nutrient receptors (Setlow, 2003; Reineke et al., 2012). During the germination process, spores progressively lose their typical resistance and become more readily inactivated like vegetative cells (Wuytac et al., 1998; Setlow, 2003; Moir, 2006; Luu and Setlow, 2014). The changes in spore sensitivity to heat and high pressure, which were used to differentiate the stages in the germination process in this work, were described by Black et al. (2007). In the first stage, the spores partially lose their impermeability to water, leading to an influx of water (with a slight increase in volume) and leakage of solutes (dipicolinic acid - DPA, $\left.\mathrm{Ca}^{2+}\right)$. Consequently, they become sensitive to wet heat (Setlow, 2003). During the second stage, the cortex is enzymatically digested, leading to full core rehydration, greater hydration of the core macromolecules, and a greater loss of spore-specific resistance, including to high pressure (Wuytac et al., 1998). At the end of the second stage, the small acid-soluble spore proteins (sasP) are hydrolyzed to amino acids, which are subsequently used in protein synthesis by the growing cell (Moir, 2006; Setlow, 2003). Protein synthesis and spore metabolism only occur in the outgrowth phase, in which the germinated spore is converted into a growing cell. According to Wuytac et al., 1998 and Reineke et al. (2012) spores are unable to proceed to stage two of germination above $500 \mathrm{MPa}$. Further spores are unable to outgrowth under pressure.

A treatment pressure above $500 \mathrm{MPa}$ combined with elevated temperatures $\left(>60^{\circ} \mathrm{C}\right)$, could induce rapid spore germination by opening the spores' $\mathrm{Ca}^{2+}$-DPA channels (Paidhungat et al., 2002), which is accompanied by the release of large depots of DPA and the associated divalent cations (predominantly $\mathrm{Ca}^{2+}$ ) from 
their core. The presumed direct opening of $\mathrm{Ca}^{2+}$-DPA channels are even active at $200 \mathrm{MPa}$ and a moderate temperature, but this is not a dominant factor influencing the germination rate (Reineke et al., 2012).

The aim of this work was to study the germination and inactivation of $A$. acidoterrestris spores induced by moderate HP and the effect of different factors, such as pressure, temperature, time, mode of pressure application, type of medium and soluble solids content in apple juice, on this process. Knowledge of factors that promote the germination step may lead to the increased lethality of HP treatments on bacterial spores.

\section{Experimental}

\section{Materials and Methods}

Tested organism. The A. acidoterrestris strain TO$-117 / 02$ used in this study was isolated from Polish concentrated apple juice, using the International Federation of Fruit Juice Producers' method. Confirmation of A. acidoterrestris was based on the utilization of erythritol, with acid production (Baumgart, 2003) and guaiacol production in YSG medium with vanillic acid (Niwa and Kawamoto, 2003). Identification at the species level was also performed by $16 \mathrm{~S} r R N A$ gene sequencing and 16S rRNA gene RFLP characterization (Dekowska et al., 2013). This strain was chosen from among eight wild strains as highly resistant to HP in our previous study (Skąpska et al., 2012). Spores were produced based on the method described by Massaguer et al. (2002), with some modifications (Sokołowska et al., 2012).

Just before the experiments, spores were suspended either in McIlvain buffer solution (mixture of relevant volume of 0.1 molar citric acid and 0.2 molar disodium phosphate) $\mathrm{pH} 4.0$ and $\mathrm{pH} 7.0$ or in apple juice at approximately 6-7 $\log \mathrm{cfu} / \mathrm{ml}$.

Hydrostatic pressure treatment. Treatment was carried out in a high pressure food processor piston type vessel with inner diameter $110 \mathrm{~mm}$, a working volume of $1.5 \mathrm{l}$, with a maximum operating pressure of $600 \mathrm{MPa}$ (Izopress, Moscow). The pressure-transmitting fluid was distilled water and polypropylene glycol $(1: 1)$. The working temperature of the apparatus was $0-50^{\circ} \mathrm{C}$. Pressure of up to $600 \mathrm{MPa}$ was generated in 15-20 s; the release time was $15 \mathrm{~s}$.

Thirteen millilitre samples in polyethylene tubes $\left(\right.$ Sarstedt $\left.{ }^{\circledast}\right)$ were exposed to high pressure treatment in a continuous or oscillatory mode with 100, 200, 300, 400 or $500 \mathrm{MPa}$ at a temperature of 20 or $50^{\circ} \mathrm{C}$. Each cycle consisted of 5 min holding time at an elevated pressure and a $5 \mathrm{~min}$ pause at atmospheric pressure. The temperature was measured in the transmitting fluid and the increase during compression was $2^{\circ} \mathrm{C} / 100 \mathrm{MPa}$.
For experiments at $70^{\circ} \mathrm{C}, \mathrm{U} 4000 / 65$ (Unipress) apparatus was used. The volume of the treatment chamber was 0.951 and the maximum pressure $600 \mathrm{MPa}$. The pressure-transmitting fluid used was also distilled water and polypropylene glycol (1:1). The working temperature of the apparatus ranged from $-10^{\circ} \mathrm{C}$ to $+80^{\circ} \mathrm{C}$. A pressure of up to $200 \mathrm{MPa}$ was generated in 120-150 s; the release time was $2-4 \mathrm{~s}$.

Unpressurized samples were used as controls. The pressurization times reported do not include the comeup and come-down time. The assays were performed using two independent samples from two independent processes.

Apple juice. Apple juice concentrate $\left(70.7^{\circ} \mathrm{Bx}, 53.0 \%\right.$ sugar, $\mathrm{pH} 3.1$, titratable acidity as malic acid 3.89\%), containing no A.acidoterrestris spores, was obtained from the Polish producer. Two-, three- and six-fold dilutions were made from this concentrate with sterile deionized water. If commercial pasteurized apple juice was used ( $\mathrm{pH} 3.4$, soluble solids $11.2^{\circ} \mathrm{Bx}$ ), before conducting the experiment it was filtered through a $0.45 \mu \mathrm{m}$ Millipore $^{\circledast}$ filter to remove possible A. acidoterrestris spores. The soluble solids and $\mathrm{pH}$ were measured using a refractometer (MS REF 090L My-Soft) and $\mathrm{pH}$ meter (CP-315 ELMETRON).

Determination of inactivation and germination of A.acidoterrestris spores. The number of spores surviving the different HP treatments was evaluated immediately after processing and after heat treatment at $80^{\circ} \mathrm{C}$ for $10 \mathrm{~min}$. This heat treatment was found not to kill ungerminated spores (data not shown). The spread plate method on BAT-agar (Merck) with incubation for 5 days at $45^{\circ} \mathrm{C}$ was used. Limit of detection this method was $1 \mathrm{cfu} / \mathrm{ml}$.

Pressure-induced inactivation was the difference between the plate count before and after HP treatment. Pressure-induced germination was the difference between the plate count before HP treatment and after $\mathrm{HP}$ followed by heat treatment at $80^{\circ} \mathrm{C}$ for 10 min (Black et al., 2007; Nguyen Thi Minh et al., 2010; Vercammen et al., 2012), expressed as log (cfu/ml).

Data analysis. An analysis of the variance and Duncan's multiple-range test, using StatSof Statistica 7.1 , was used to test the significance of the differences $(p<0.05)$ between the number of germinated and inactivated spores. The bars on the figures indicate the mean standard deviation for data points.

\section{Results and Discussion}

Influence of pressure and type of medium on the germination and inactivation of A.acidoterrestris spores. To study the effect of moderate pressure on the germination and inactivation of A.acidoterrestris 
Table I

The germination and inactivation of A. acidoterrestris spores under various pressures at low and neutral $\mathrm{pH}$ in buffer solutions and commercial apple juice (HP treatment at $50^{\circ} \mathrm{C}$ for $20 \mathrm{~min}$ ).

\begin{tabular}{|c|c|c|c|c|c|c|}
\hline \multirow[b]{2}{*}{$\begin{array}{c}\text { Pressure } \\
{[\mathrm{MPa}]}\end{array}$} & \multicolumn{2}{|c|}{ McIlvain buffer $\mathrm{pH} 4.0$} & \multicolumn{2}{|c|}{ McIlvain buffer $\mathrm{pH} 7.0$} & \multicolumn{2}{|c|}{ Commercial apple juice } \\
\hline & $\begin{array}{c}\text { Germination } \\
\log [\mathrm{cfu} / \mathrm{ml}]\end{array}$ & $\begin{array}{l}\text { Inactivation } \\
\log [\mathrm{cfu} / \mathrm{ml}]\end{array}$ & $\begin{array}{c}\text { Germination } \\
\log [\mathrm{cfu} / \mathrm{ml}]\end{array}$ & $\begin{array}{l}\text { Inactivation } \\
\log [\mathrm{cfu} / \mathrm{ml}]\end{array}$ & $\begin{array}{c}\text { Germination } \\
\log [\mathrm{cfu} / \mathrm{ml}]\end{array}$ & $\begin{array}{l}\text { Inactivation } \\
\log [\mathrm{cfu} / \mathrm{ml}]\end{array}$ \\
\hline 100 & $3.14 \pm 0.03^{\mathrm{bA}}$ & $1.85 \pm 0.13^{\mathrm{baA}}$ & $2.95 \pm 0.02^{\mathrm{aB}}$ & $0.24 \pm 0.09^{\mathrm{aB}}$ & $3.06 \pm 0.03^{\mathrm{aA}}$ & $1.83 \pm 0.06^{\mathrm{aA}}$ \\
\hline 200 & $3.75 \pm 0.18^{\mathrm{aA}}$ & $2.02 \pm 0.02^{\mathrm{baA}}$ & $2.84 \pm 0.34^{\mathrm{aB}}$ & $0.31 \pm 0.04^{\mathrm{abB}}$ & $3.59 \pm 0.10^{\mathrm{bA}}$ & $1.95 \pm 0.12^{\mathrm{aA}}$ \\
\hline 300 & $3.74 \pm 0.05^{\mathrm{aA}}$ & $2.04 \pm 0.05^{\mathrm{aA}}$ & $2.73 \pm 0.07^{\mathrm{aB}}$ & $0.38 \pm 0.06^{\mathrm{bB}}$ & $3.30 \pm 0.01^{\mathrm{cC}}$ & $1.85 \pm 0.06^{\mathrm{aA}}$ \\
\hline 400 & $3.39 \pm 0.06^{\mathrm{bA}}$ & $1.84 \pm 0.06^{\mathrm{bA}}$ & $2.69 \pm 0.09^{\mathrm{aB}}$ & $1.06 \pm 0.03^{\mathrm{cB}}$ & $2.88 \pm 0.02^{\mathrm{dB}}$ & $1.26 \pm 0.03^{\mathrm{bC}}$ \\
\hline 500 & $3.32 \pm 0.12^{\mathrm{bA}}$ & $1.37 \pm 0.05^{\mathrm{cA}}$ & $1.86 \pm 0.02^{\mathrm{bB}}$ & $0.66 \pm 0.01^{\mathrm{dB}}$ & $1.73 \pm 0.01^{\mathrm{eB}}$ & $0.85 \pm 0.02^{\mathrm{cC}}$ \\
\hline
\end{tabular}

Mean values in columns with different lowercase letters are significantly different at $p<0.05$, separately for germination and inactivation. Mean values in rows with different capital letters are significantly different at $p<0.05$, separately for germination and inactivation.

spores, a temperature of $50^{\circ} \mathrm{C}$ was chosen to stimulate germination without causing a thermal pasteurization effect. Low (4.0) and neutral (7.0) pH buffers and real food - apple juice - were used in this part of the study.

Germination of spores was observed in all used media (Table I). The highest germination, from 3.14 to $3.75 \mathrm{log}$, was found in the $\mathrm{pH} 4.0$ buffer within the entire range of applied pressure. Statistically significant $(p<0.05)$ maximum germination occurred at 200 and $300 \mathrm{MPa}$ in the $\mathrm{pH} 4.0$ buffer. Similar germination was observed in apple juice pressurized at $200 \mathrm{MPa}$ - $3.59 \mathrm{log}$. Generally the lowest germination was obtained in the $\mathrm{pH} 7.0$ buffer, but the results noted in the pressure range 100-400 MPa did not differ significantly $(p>0.05)$.

Significant $(p<0.05)$ inactivation, of $1.84-2.04 \mathrm{log}$, was observed in the $\mathrm{pH} 4.0$ buffer as a result of pressure treatment in the 100-400 MPa range. The level of inactivation in apple juice was similar - a reduction from 1.83 to $1.95 \log$ was achieved in the slightly narrower 100-300 MPa range. Less inactivation occurred at 400 or $500 \mathrm{MPa}$,

A. acidoterrestris spores germinated in the $\mathrm{pH} 7.0$ buffer but were not inactivated during HP treatment. Inactivation only reached $0.24-1.06 \mathrm{log}$, with a significant maximum $(p<0.05)$ at $400 \mathrm{MPa}$ (Table I).

The results indicate that a low $\mathrm{pH}$ supports both the germination and inactivation of $A$. acidoterrestris spores. In our study the highest germination was achieved when $200-300 \mathrm{MPa}$ in $\mathrm{pH} 4.0$ buffer or $200 \mathrm{MPa}$ in apple juice at $50^{\circ} \mathrm{C}$ was used, which is consistent with the results obtained by Vercammen et al. (2012).

Considerable inactivation of $A$. acidoterrestris spores was also achieved in our study. In apple juice in the low pressure window (100-300 $\mathrm{MPa})$, the reduction was significantly higher than at 400 or $500 \mathrm{MPa}$. Contrary to our results, in the Lee et al. (2002) study there was no significant difference among the effect of 207, 414 and $621 \mathrm{MPa}$ on A. acidoterrestris spore viability at $45^{\circ} \mathrm{C}$ in apple juice, a $3.5 \log$ reduction was always observed, irrespective of the pressure used. Yet other results were obtained by Silva et al. (2012) in orange juice. When processed at $45^{\circ} \mathrm{C}$, the inactivation of spores treated with $200 \mathrm{MPa}$ was only about $0.5 \mathrm{log}$ and about $1.0 \mathrm{log}$, when $600 \mathrm{MPa}$ was used. The different results obtained in the work presented may indicate large variations in pressure resistance among the A. acidoterrestris strains, as well as the influence of the kind of juice, sporulation conditions and equipment used in the various studies.

Impact of temperature and time on the germination and inactivation of $A$.acidoterrestris spores in apple juice during pressure treatment. For this study, pressure of $200 \mathrm{MPa}$ was chosen as the best for germination and inactivation of A.acidoterrestris spores in apple juice. As shown in Figure 1, the germination of A. acidoterrestris spores in apple juice depended on the temperature and time. At $20^{\circ} \mathrm{C}$ there was little germination and $2.04 \mathrm{log}$ was achieved after $30 \mathrm{~min}$, while inactivation in these conditions achieved only $0.61 \mathrm{log}$. After $5 \mathrm{~min}$ at $50^{\circ} \mathrm{C}$, the degree of germination was $2.65 \mathrm{log}$, but the spores did not inactivated. Prolonging the time of treatment at $50^{\circ} \mathrm{C}$ to $30 \mathrm{~min}$, significantly $(p<0.05)$ supported both germination and inactivation, which resulted in $4.06 \mathrm{log}$ of germinated spores and $2.76 \log$ of inactivated spores.

When HP treatment was conducted at $70^{\circ} \mathrm{C}$, germination was significantly higher $(p<0.05)$ than at $50^{\circ} \mathrm{C}$ for all used pressurization times. Most of the germinated spores were also inactivated at $70^{\circ} \mathrm{C}$. Treatment at this temperature was found not to kill ungerminated spores, but to cause a thermal pasteurization effect on vegetative cells. Approx. $1.7 \mathrm{log}$ of A. acidoterrestris TO-117/02 strain vegetative cells was inactivated after $30 \mathrm{~min}$ at $70^{\circ} \mathrm{C}$ (data not shown).

The highest germination and inactivation were achieved when $200 \mathrm{MPa}$ was applied at $70^{\circ} \mathrm{C}$, which is consistent with the results obtained by other researchers (Silva et al., 2012; Vercammen et al., 2012). Spores of the A.acidoterrestris TO-117/02 strain used in our study showed higher resistance to $\mathrm{HP}$ at $70^{\circ} \mathrm{C}$ than the 


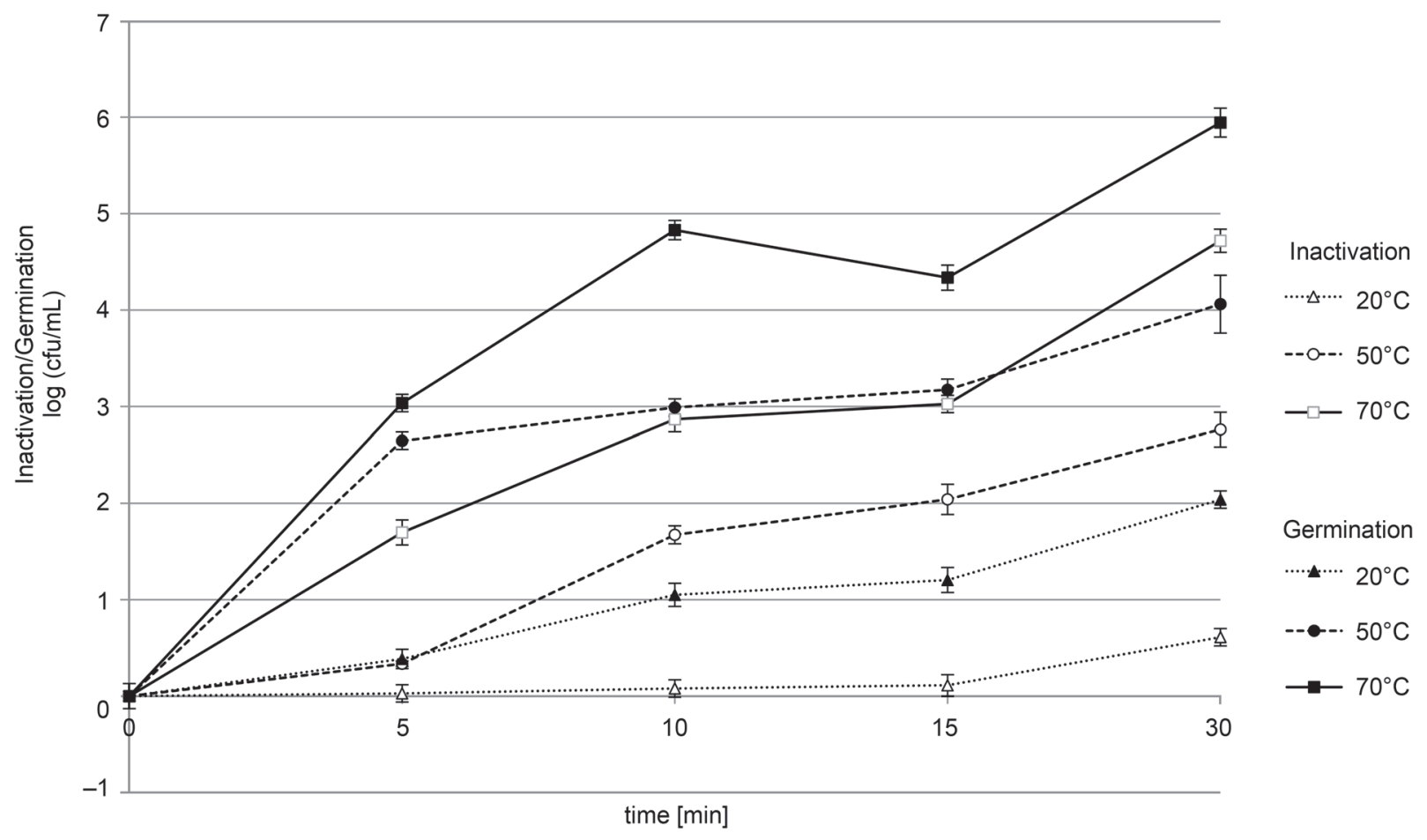

Fig. 1. Germination and inactivation of A. acidoterrestris spores treated with $200 \mathrm{MPa}$ in commercial apple juice at various temperatures.

strain used by Lee et al. (2002), who observed a complete $(>5.5 \mathrm{log})$ reduction in apple juice after $5 \mathrm{~min}$ treatment with $207 \mathrm{MPa}$ at $71^{\circ} \mathrm{C}$.

The higher spore inactivation rate at a higher temperature can be explained by the acceleration of enzymatic reactions during progression from the first to second stage of germination as well as by the fact that first stage germinated spores are directly inactivated by temperatures above $70^{\circ} \mathrm{C}$ (Nguyen Thi Minh et al., 2010).

Since pressurization conducted at $500 \mathrm{MPa}$ at $50^{\circ} \mathrm{C}$ resulted in the lowest germination and inactivation, it was also verified whether an increase in temperature would enhance these processes. A higher process temperature $\left(70^{\circ} \mathrm{C}\right)$ strongly stimulated germination and inactivation at $500 \mathrm{MPa}$. The germination achieved
$6.72 \mathrm{log}$ and inactivation $6.13 \mathrm{log}$ and the increase was significantly higher than at a lower $(200 \mathrm{MPa})$ pressure (Table II). This phenomenon was also observed in tomato juice (Vercammen et al., 2012).

Effect of mode of pressure application on the germination and inactivation of $A$. acidoterrestris spores. Samples of A.acidoterrestris spores in buffer solutions ( $\mathrm{pH} 4.0$ and 7.0) and apple juice were exposed to hydrostatic pressure treatment in continuous or oscillatory mode with $200 \mathrm{MPa}$ at a temperature of $50^{\circ} \mathrm{C}$. Each cycle was composed of 5 min holding time at an elevated pressure and a $5 \mathrm{~min}$ pause at atmospheric pressure.

The degree of germination and inactivation of $\mathrm{A}$. acidoterrestris spores increased when the pressure time was prolonged and the $\mathrm{pH}$ decreased (Table III). After

Table II

Germination and inactivation of $A$. acidoterrestris spores after 20 min under various pressures and temperature in commercial apple juice.

\begin{tabular}{|c|c|c|c|c|}
\hline \multirow{2}{*}{$\begin{array}{c}\text { Pressure } \\
{[\mathrm{MPa}]}\end{array}$} & \multicolumn{3}{|c|}{ Pressurization temperature } \\
\cline { 2 - 5 } & $\begin{array}{c}\text { Germination } \\
\log [\mathrm{cfu} / \mathrm{ml}]\end{array}$ & $\begin{array}{c}\text { Inactivation } \\
\log [\mathrm{cfu} / \mathrm{ml}]\end{array}$ & $\begin{array}{c}\text { Germination } \\
\log [\mathrm{cfu} / \mathrm{ml}]\end{array}$ & $\begin{array}{c}\text { Inactivation } \\
\log [\mathrm{cfu} / \mathrm{ml}]\end{array}$ \\
\hline 200 & $3.59 \pm 0.10^{\mathrm{aA}}$ & $1.95 \pm 0.12^{\mathrm{aA}}$ & $5.84 \pm 0.04^{\mathrm{aB}}$ & $3.99 \pm 0.07^{\mathrm{aB}}$ \\
\hline 500 & $1.73 \pm 0.01^{\mathrm{bA}}$ & $0.85 \pm 0.02^{\mathrm{bA}}$ & $6.72 \pm 0.00^{\mathrm{bB}}$ & $6.13 \pm 0.16^{\mathrm{bB}}$ \\
\hline
\end{tabular}

Mean values in columns with different lowercase letters are significantly different at $p<0.05$, separately for germination and inactivation.

Mean values in rows with different capital letters are significantly different at $p<0.05$, separately for germination and inactivation. 
Table III

Germination and inactivation of A. acidoterrestris spores treated with $200 \mathrm{MPa}$ at low and neutral $\mathrm{pH}$ in buffer solutions and in commercial apple juice (HP treatment at $50^{\circ} \mathrm{C}$ ).

\begin{tabular}{|c|c|c|c|c|c|c|}
\hline \multirow{2}{*}{$\begin{array}{l}\text { Time } \\
\text { [min] }\end{array}$} & \multicolumn{2}{|c|}{ McIlvain buffer $\mathrm{pH} 4.0$} & \multicolumn{2}{|c|}{ McIlvain buffer $\mathrm{pH} 7.0$} & \multicolumn{2}{|c|}{ Commercial apple juice } \\
\hline & $\begin{array}{c}\text { Germination } \\
\log [\mathrm{cfu} / \mathrm{ml}]\end{array}$ & $\begin{array}{l}\text { Inactivation } \\
\log [\mathrm{cfu} / \mathrm{ml}]\end{array}$ & $\begin{array}{c}\text { Germination } \\
\log [\mathrm{cfu} / \mathrm{ml}]\end{array}$ & $\begin{array}{l}\text { Inactivation } \\
\log [\mathrm{cfu} / \mathrm{ml}]\end{array}$ & $\begin{array}{c}\text { Germination } \\
\log [\mathrm{cfu} / \mathrm{ml}]\end{array}$ & $\begin{array}{l}\text { Inactivation } \\
\log [\mathrm{cfu} / \mathrm{ml}]\end{array}$ \\
\hline 5 & $1.84 \pm 0.01^{\mathrm{aA}}$ & $0.18 \pm 0.00^{\mathrm{aA}}$ & $1.67 \pm 0.06^{\mathrm{aA}}$ & $0.07 \pm 0.00^{\mathrm{aB}}$ & $2.65 \pm 0.09^{\mathrm{aB}}$ & $0.34 \pm 0.03^{\mathrm{aC}}$ \\
\hline 10 & $2.31 \pm 0.02^{\mathrm{bA}}$ & $0.75 \pm 0.03^{\mathrm{bA}}$ & $2.12 \pm 0.05^{\mathrm{bB}}$ & $0.14 \pm 0.02^{\mathrm{bB}}$ & $2.99 \pm 0.05^{\mathrm{abC}}$ & $1.67 \pm 0.09^{\mathrm{bC}}$ \\
\hline 15 & $2.64 \pm 0.04^{\mathrm{cA}}$ & $1.15 \pm 0.04^{\mathrm{cA}}$ & $2.62 \pm 0.01^{\mathrm{cA}}$ & $0.23 \pm 0.02^{\mathrm{cB}}$ & $3.17 \pm 0.08^{\mathrm{bB}}$ & $2.04 \pm 0.16^{\mathrm{cC}}$ \\
\hline 30 & $3.24 \pm 0.00^{\mathrm{dA}}$ & $1.79 \pm 0.00^{\mathrm{dA}}$ & $3.06 \pm 0.00^{\mathrm{dA}}$ & $0.24 \pm 0.01^{\mathrm{cB}}$ & $4.06 \pm 0.30^{\mathrm{cB}}$ & $2.78 \pm 0.03^{\mathrm{dC}}$ \\
\hline
\end{tabular}

Mean values in columns with different lowercase letters are significantly different at $p<0.05$, separately for germination and inactivation. Mean values in rows with different capital letters are significantly different at $p<0.05$, separately for germination and inactivation.

Table IV

Germination and inactivation of A. acidoterrestris spores treated with oscillatory pressure $200 \mathrm{MPa}$ at low and neutral $\mathrm{pH}$ in buffer solutions and in apple juice (HP treatment at $\left.50^{\circ} \mathrm{C}\right)$.

\begin{tabular}{|l|l|l|l|l|l|c|}
\hline \multirow{2}{*}{$\begin{array}{c}\text { Number } \\
\text { of cycle }\end{array}$} & \multicolumn{2}{|c|}{ McIlvain buffer $\mathrm{pH} 4.0$} & \multicolumn{2}{c|}{ Mcllvain buffer $\mathrm{pH} 7.0$} & \multicolumn{2}{c|}{ Commercial apple juice } \\
\cline { 2 - 7 } & $\begin{array}{c}\text { Germination } \\
\log [\mathrm{cfu} / \mathrm{ml}]\end{array}$ & $\begin{array}{c}\text { Inactivation } \\
\log [\mathrm{cfu} / \mathrm{ml}]\end{array}$ & $\begin{array}{c}\text { Germination } \\
\log [\mathrm{cfu} / \mathrm{ml}]\end{array}$ & $\begin{array}{c}\text { Inactivation } \\
\log [\mathrm{cfu} / \mathrm{ml}]\end{array}$ & $\begin{array}{c}\text { Germination } \\
\log [\mathrm{cfu} / \mathrm{ml}]\end{array}$ & $\begin{array}{c}\text { Inactivation } \\
\log [\mathrm{cfu} / \mathrm{ml}]\end{array}$ \\
\hline 2 & $2.72 \pm 0.06^{\mathrm{aA}}$ & $1.57 \pm 0.05^{\mathrm{aA}}$ & $2.19 \pm 0.09^{\mathrm{aB}}$ & $0.09 \pm 0.05^{\mathrm{aB}}$ & $3.11 \pm 0.18^{\mathrm{aA}}$ & $1.48 \pm 0.27^{\mathrm{aA}}$ \\
\hline 4 & $3.45 \pm 0.04^{\mathrm{bA}}$ & $2.28 \pm 0.05^{\mathrm{bA}}$ & $2.89 \pm 0.03^{\mathrm{bB}}$ & $0.20 \pm 0.15^{\mathrm{abB}}$ & $3.61 \pm 0.06^{\mathrm{bC}}$ & $2.40 \pm 0.03^{\mathrm{bA}}$ \\
\hline 6 & $3.89 \pm 0.10^{\mathrm{cA}}$ & $2.67 \pm 0.01^{\mathrm{cA}}$ & $3.38 \pm 0.03^{\mathrm{BB}}$ & $0.46 \pm 0.04^{\mathrm{bB}}$ & $4.04 \pm 0.01^{\mathrm{CA}}$ & $2.70 \pm 0.04^{\mathrm{bA}}$ \\
\hline
\end{tabular}

Mean values in columns with different lowercase letters are significantly different at $p<0.05$, separately for germination and inactivation. Mean values in rows with different capital letters are significantly different at $p<0.05$, separately for germination and inactivation.

30 min of continuous pressurization with $200 \mathrm{MPa}$ at $50^{\circ} \mathrm{C}, 3.06 \log$ of spores suspended in $\mathrm{pH} 7$ buffer germinated, but only $0.24 \log$ was inactivated. Germination in a $\mathrm{pH} 4.0$ buffer and in commercial apple juice was higher (3.24 and 4.06 log respectively). In these conditions inactivation achieved $1.79 \log$ in a $\mathrm{pH} 4.0$ buffer and $2.78 \mathrm{log}$ in apple juice. Part of the spore population still remained ungerminated.

The results achieved in this part of our study also show that the nutrients present in commercial apple juice can promote the germination of $A$. acidoterrestris spores during pressurization under moderate HP. The same phenomenon was observed by Vercammen et al. (2012), in tomato juice.

Many studies have demonstrated that the application of pressure cycling is more efficient than constant pressure treatment when the total exposure is equivalent (Hayakawa et al., 1994; Furukawa et al., 2000; Sokołowska et al., 2012). Furukawa et al. (2000) concluded that hydrostatic pressure treatment initiated the germination of bacterial spores, and that repeated rapid decompression caused disruption, injury and inactivation of the germinated spores. Nguyen Thi Minh et al. (2010) suggest that after inducing germination of spores under the first pressure treatment, decompression between the pressure cycles favours the progression from first stage to second stage of the germinated spores. The second stage germinated spores are then inactivated by subsequent pressure cycles, which would explain the greater spore destruction by pressure cycling. Recently this statement was disproven by Kong et al. (2014), who observed that spore germination stopped 5 to $10 \mathrm{~min}$ after the HP was released. Obtained in those study results suggest that an HP of $150 \mathrm{MPa}$ for $<30 \mathrm{~s}$ is sufficient to fully activate spores' germinant receptors (GRs), which remain activated at $1 \mathrm{MPa}$ but can deactivate at ambient pressure.

The results obtained (Table IV) showed that spores germinated after 2 cycles: $2.72 \log$ in $\mathrm{pH} 4.0$ buffer or $3.11 \mathrm{log}$ in apple juice. Germination achieved 3.89 log in pH 4.0 buffer and $4.04 \log$ in apple juice after 6 cycles. Inactivation was also effective and achieved 2.67 log and $2.70 \log$ respectively. These results did not differ significantly $(p>0.05)$ for both media. Only after 4 cycles germination in apple juice was significantly higher than in $\mathrm{pH} 4.0$ buffer.

Slightly, but significantly less $(p<0.05)$ germination was observed in $\mathrm{pH} 7.0$ buffer but inactivation in these conditions was very small. After 6 cycles in $\mathrm{pH} 7.0$ buffer, $3.38 \mathrm{log}$ of spores germinated and only $0.46 \mathrm{log}$ were inactivated.

The application of pressure in the oscillatory mode gave a slightly but significantly better effect on the germination and inactivation of $A$.acidoterrestris spores compared to a continuous process in buffers. In apple juice, the differences were not significant. 


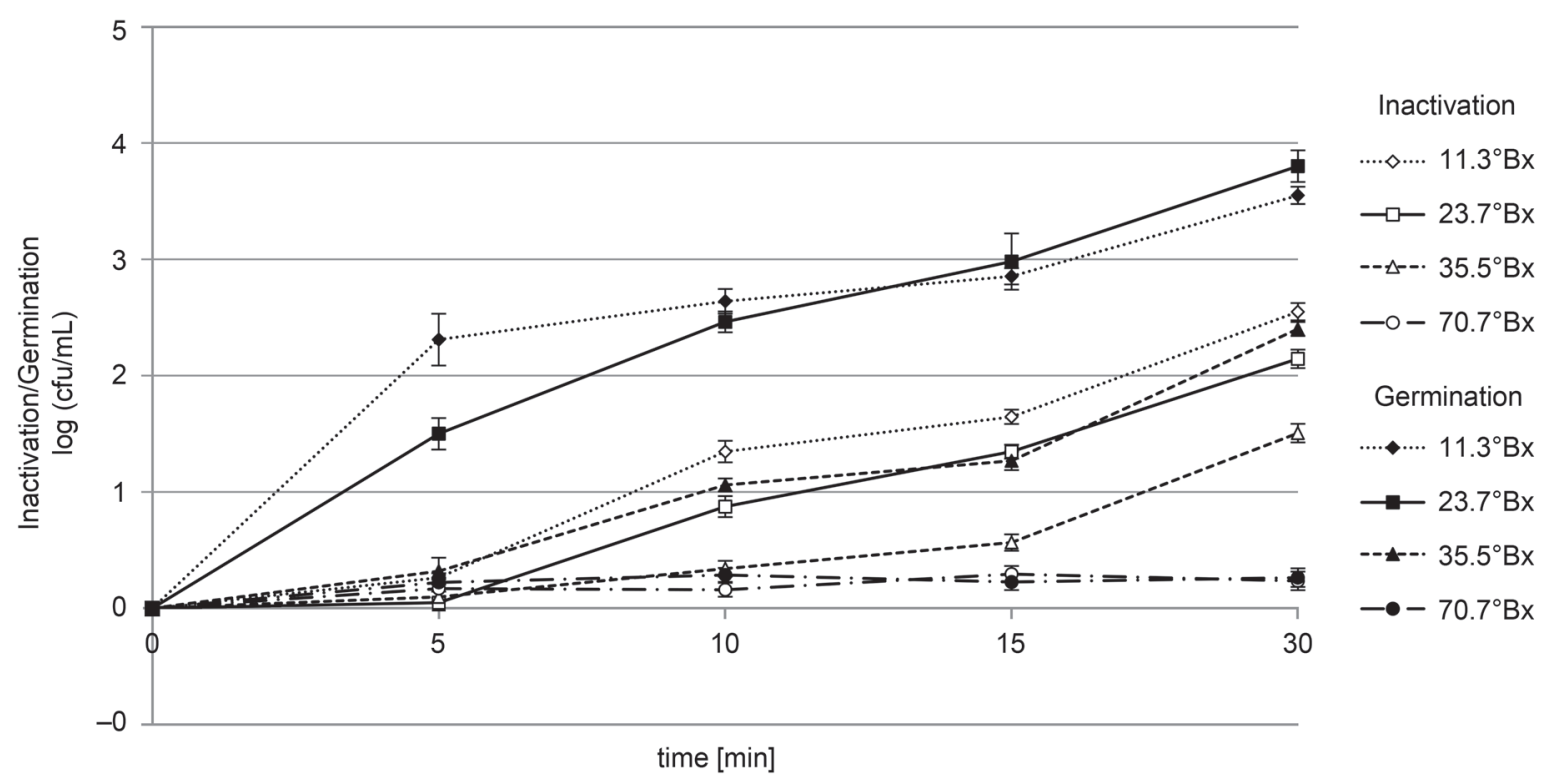

Fig. 2. Germination and inactivation of A. acidoterrestris spores treated with $200 \mathrm{MPa}$ in apple juice with various soluble solids content (HP treatment at $50^{\circ} \mathrm{C}$ ).

Inactivation was also low, compared to the results obtained in our previous study (Sokołowska et al., 2012). In those experiments A.acidoterrestris TO-29/4/02 strain was used and inactivation achieved $5.0 \log$ after 6 cycles at $50^{\circ} \mathrm{C}$ with $200 \mathrm{MPa}$, while $2.8 \log$ inactivation was achieved after $30 \mathrm{~min}$ of continuous pressurization.

These different results may indicate large variations in the germination process under pressure, among A. acidoterrestris strains.

Influence of soluble solids content in apple juice on the germination and inactivation of A. acidoterrestris spores during pressurization. In this study pressure of $200 \mathrm{MPa}$ at $50^{\circ} \mathrm{C}$ was used to investigate the influence of soluble solids content in apple juice on the germination of $A$. acidoterrestris spores.

As we expected after previous study (Sokołowska et al., 2013) The baroprotective effect of an increase in the solute concentration in apple juice on A.acidoterrestris spores during high pressure processing was observed (Fig. 2). During $30 \mathrm{~min}$ pressurization of spores in concentrated apple juice $\left(70.7^{\circ} \mathrm{Bx}\right)$, there was no significant germination and inactivation $(p>0.05)$. However, in juices with a soluble solids content of 35.7, 23.6 and $11.2^{\circ} \mathrm{Bx}$, the spore germination was $2.40,3.80$ and $3.55 \mathrm{log}$ after $30 \mathrm{~min}$. In the same conditions inactivation was $1.51 \mathrm{log}, 2.14$ and $2.55 \mathrm{log}$, respectively. The results obtained demonstrate that the effect of high pressure combined with heat, against $A$. acidoterrestris spores, was highly dependent on the concentration of apple juice.

Similar results for the inactivation of spores were obtained by Lee et al. (2006). In the case of apple juice concentrate $\left(70^{\circ} \mathrm{Bx}\right)$, treatment with high pressure $(207$, 414 and $621 \mathrm{MPa})$ at four different temperatures $(22,45$,
71 and $90^{\circ} \mathrm{C}$ ) showed no inactivating effect against the spores of A.acidoterrestris after $10 \mathrm{~min}$ of treatment. In diluted apple juice $\left(17.5^{\circ} \mathrm{Bx}\right) \mathrm{A}$. acidoterrestris spore reductions was more than $5 \log$ after $10 \mathrm{~min}$ at higher temperatures $\left(71\right.$ and $\left.90^{\circ} \mathrm{C}\right)$.

Increasing spore resistance with a greater soluble solids content may be explained by the lower $\mathrm{a}_{\mathrm{w}}$ as well as by the protective effect of sugars. At low $\mathrm{a}_{\mathrm{w}}$ germination may be incomplete as a result of water deficiency (Black et al., 2007). A baroprotective effect of sugars was also reported for spores (Raso et al., 1998).

Conclusions. The results of this study indicate that the treatment conditions, i.e. the level of pressure used and the temperature, time and mode of pressure application as well as, type and $\mathrm{pH}$ of the media and soluble solids content in apple juice considerably influenced the germination and inactivation of A. aciodoterrestris spores. These factors should be kept in mind when designing moderate pressure treatments to assure the safety and stability of foods.

It was demonstrated that hydrostatic pressure treatment could induce germination and inactivation of $A$. acidoterrestris spores. A low $\mathrm{pH}$ favoured their germination and inactivation while a neutral $\mathrm{pH}$ suppressed inactivation. Increasing the process temperature strongly stimulated spore germination and inactivation. When the oscillatory mode was used the degree of germination and inactivation were slightly higher than at continuous mode. The degree of germination and inactivation was inversely proportional to the soluble solids content and was lowest in concentrated apple juice.

These results indicate that high inactivation of $\mathrm{A}$. acidoterrestris spores might be possible by HP treatment 
conducted at a moderately elevated temperature or followed by moderate heat treatment. This would allow better retention of the original properties, nutrients and bioactive components of the juices and make it possible to eliminate these spoilage bacteria.

\section{Acknowledgments}

The study was financed by the National Science Centre (Poland) Polish Ministry of Science and Higher Education under via grant No. 2011/01/B/NZ9/02537.

\section{Literature}

Ardia A. 2004. Ph.D. Thesis. Process Considerations on the Application of High Pressure Treatment at Elevated Temperature Levels for Food Preservation. Technical University of Berlin. Berlin. Germany. Alpas H., L. Alma and F. Bozoglu. 2003. Inactivation of Alicyclobacillus acidoterrestris vegetative cells in model system, apple, orange and tomato juice by high hydrostatic pressure. World J. Microbiol. Biotech. 19: 619-623.

Bahçeci K.S. and J. Acar. 2007. Modeling the combined effects of $\mathrm{pH}$, temperature and ascorbic acid concentration on the heat resistance of Alicyclobacillus acidoterrestris. Int. J. Food Microbiol. 120(3): 266-273.

Baumgart J. 2003. Media for the detection and enumeration of Alicyclobacillus acidoterrestris and Alicylobacillus acidocaldarius in foods, pp 161-166. In: Corry J.E.L., G.D.W. Curtis and R.M. Baird (eds). Handbook of culture media for food microbiology. Progress in industrial microbiology Vol. 37. Elsevier, Amsterdam.

Baumgart J., M. Husemann and C. Schmidt. 1997. Alicyclobacillus acidoterrestris: Vorkommen, Bedeutung und Nachweis in Getränken und Getränkegrundstoffen. Fluss Obst 64: 178-180.

Bevilacqua A. and M.R. Corbo. 2011. Characterization of a wild strain of Alicyclobacillus acidoterrestris: heat resistance and implications for tomato juice. J. Food Sci. 76(2): M130-M136.

Black E., P. Setlow, A.D. Hocking, C.M. Stewart, A.L. Kelly and D.G. Hoover. 2007. Response of spores to high - pressure processing. Com. Rev. Food Sci. Food Safety 6: 103-119.

Borlinghaus A. and R. Engel. 1997. Alicyclobacillus incidence in commercial apple juice concentrate (AJC) supplies and validation. Fruit Process. 7(7): 262-266.

Cerny G., W. Hennlich and K. Poralla. 1984. Isolation and characterisation of bacilli cause spoilage of fruit juices (in German). Z Lebensmitt. Untersuch. Forsch. 179: 224-227.

Danyluk M.D., L.M. Friedrich, C. Jouquand, R. GoodrichSchneider, M.E. Parish and R. Rouseff. 2011. Prevalence, concentration, spoilage, and mitigation of Alicyclobacillus spp. in tropical and subtropical fruit juice concentrates. Food Microbiol. 28: 472-477.

Deinhard G., P. Blanz, K. Poralla and E. Altan. 1987. Bacillus acidoterrestris sp. nov., a new thermotolerant acidophile isolated from different soils. Syst. Appl. Microbiol. 10: 47-53.

Dekowska A., J. Niezgoda and B. Sokołowska. 2013. Genetic diversity of Alicyclobacillus species isolated from Polish fruit juices. Abstract of $V$ International Conference on Environmental, Industrial and Applied Microbiology, BioMicroWorld 2013, Madrid. Spain. p. 216.

Durak M.Z., J.J. Churey, M.D. Danyluk and R.W. Worobo. 2010. Identification and haplotype distribution of Alicyclobacillus spp. from different juices and beverages. Int. J. Food Microbiol. 142: 286-291.
Eguchi S.Y., G.P. Manfio, M.E. Pinhatti, E. Azuma and S.F. Variane. 2001. Acidotermofilic sporeforming bacteria (ATSB) in orange juices: ecology, and involvement in the deterioration of fruit juices - Report of the Research Project. Part II. Fruit Process. 11(2): 55-62.

Furukawa S., A. Nakahara and I. Hayakawa. 2000. Effect of reciprocal pressurization on germination and killing of bacterial spores. Int. J. Food Sci. Technol. 35: 529-532.

Gocmen D., A. Elston, T. Williams, M. Parish and R.L. Housett. 2005. Identification of medicinal off-flavours generated by Alicyclobacillus species in orange juice using GC-olfactometry and GC-MS. Lett. Appl. Microbiol. 40: 172-177.

Goto K., A. Nishibori, Y. Wasada, K. Furuhata, M. Fukuyama and M. Hara. 2008. Identification of thermo-acidophilic bacteria isolated from the soil of several Japanese fruit orchards. Lett. Applied. Microbiol. 46: 289-294.

Groenewald W.H., P.A. Gouws and R.C. Witthuhn. 2008. Isolation and identification of species of Alicyclobacillus from orchard soil in the Western Cape, South Africa. Extremophiles. 12: 159-163. Hayakawa L., T Kanno, K. Yoshiyama and Y. Fujio. 1994. Oscillatory compared with continuous high pressure sterilization on Bacillus stearothermophilus spores. J. Food Sci. 59: 164-167.

International Federation of Fruit Juice Producers (IFU). 2006. Method on the Detection of Alicyclobacillus in Fruit Juices. IFU Method No. 12, IFU Paris.

Jensen N. and F.B. Whitfield. 2003. Role of Alicyclobacillus acidoterrestris in the development of a disinfectant taint in shelf-stable fruit juice. Lett. Appl. Microbiol. 36: 9-14.

Kirschke W. and K. Poralla. 1990. Properties of Bacillus acidocaldarius mutants deficient in $\omega$-cyclohexyl fatty acid biosynthesis. Arch. Microbiol. 153: 463-469.

Komitopoulou E., I.S. Boziaris, E.A. Davies, J. Delves-Broughton and M.R. Adams. 1999. Alicyclobacillus acidoterrestris in fruit juices and its control by nisin. Int. J. Food Sci. Technol. 34: 81-85.

Kong L., C.J. Doona, P. Setlow and Y. Li. 2014. Monitoring Rates and Heterogeneity of High-Pressure Germination of Bacillus Spores by Phase-Contrast Microscopy of Individual Spores. Appl. Environ. Microbiol. 80(1): 345-353.

Lee S.Y., H.J. Chung and D.H. Kang. 2006. Combined treatment of high pressure and heat on killing spores of Alicyclobacillus acidoterrestris in apple juice concentrate. J. Food Protect. 69(5): 1056-1060.

Lee S.Y., R.H. Dougherty and D.H. Kang. 2002. Inhibitory effect of high pressure and heat on Alicyclobacillus acidoterrestris spores in apple juice. Appl. Environ. Microbiol. 68: 4158-4161.

Luu S. and P. Setlow. 2014. Analysis of the loos in heat and acid resistance during germination of spores of Bacillus species. J. Bacteriol. 196(9): 1733-1740.

Massaguer P.R., C.P. Pacheco, M.M. Atarassi, W.L. Peña, A.C. Gonçalves, N.A. Paula, L.H. Geraldini, L.L. Liossi, M.R. Gagliazzi and V.A. Guerra. 2002. Sensibility and specificity of methods for Alicyclobacillus detection and quantification: a collaborative study. Fruit Process 12: 478-482.

Moir A. 2006. How do spores germinate? J. Appl. Microbiol. 10(3): 526-530.

McKnight I.C., M.N.U Eiroa, A.S. Sant'Ana and P.R. Massaguer. 2010. Alicyclobacillus acidoterrestris in pasteurized exotic Brazilian fruit juices: isolation, genotypic characterization and heat resistance. Food Microbiol. 27: 1016-1022.

Niwa M. 2005. Control of hazardous bacteria in acidic beverages by using a guaiacol detection kit (peroxidase method). Fruit Process. 15(6): 388-392.

Niwa M. and A. Kawamoto. 2003. Development of a rapid detection method of A. acidoterrestris, hazardous bacteria to acidic beverage. Fruit Process. 13: 102-107. 
Nguen Thi Minh H., P. Dantigny, J.-M. Perrier-Cornet and P. Gervais. 2010. Germination and inactivation of Bacillus subtilis spores induced by moderate hydrostatic pressure. Biotech. Bioeng. 107(5): 876-883.

Oteiza J.M., G. Ares, A.S. Sant'Ana, S. Soto and L. Giannuzzi. 2011. Use a multivariate approach to assess the incidence of Alicyclobacillus spp. In concentrate fruit juices marketed in Argentina: Results of a 14-year survey. Int. J. Food Microbiol. 151: 229-234.

Orr R.V., R.L. Shewfelt, C.J. Huang, S. Tefera and L.R. Beuchat. 2000. Detection of guaiacol produced by Alicyclobacillus acidoterrestris in apple juice by sensory and chromatographic analyses, and comparison with spore and vegetative cell populations. J. Food Protect. 11: 1517-1522.

Paidhungat M., B. Setlow, W.B. Daniels, D. Hoover, E. Papafragkou and P. Setlow. 2002. Mechanisms of induction of germination of Bacillus subtilis spores by high Pressure. Appl. Environ. Microbiol. 68(6): 3172-3175.

Parish M.E. and R.M. Goodrich. 2005. Recovery of presumptive Alicyclobacillus strains from orange fruit surfaces. J. Food Protect. 68(10): 2196-2200.

Pettipher G.L., M.E. Osmundson and J.M. Murphy. 1997. Methods for the detection and enumeration of Alicyclobacillus acidoterrestris and investigation of growth and production of taint in fruit juice and fruit juice-containing drinks. Lett. Appl. Microbiol. 24: 185-189.

Reineke K., I. Doehner, K. Schlumbach, D. Baier, A. Mathys and D. Knor. 2012. The different pathways of spore germination and inactivation in dependence of pressure and temperature. Innov. Food Sci. Emerg. Tech. 13: 31-41.

Raso J., M.M. Gongora-Nieto, G.V. Barbosa-Cenovas and B.G. Swanson. 1998. Influence of several environmental factors on the initiation of germination and inactivation of Bacillus cereus by high hydrostatic pressure. Int. J. Food Microbiol. 44: 125-132.

Setlow P. 2003. Spore germination. Curr. Opin. Microbiol. 6(6): 550-556.

Silva F.V.M., P. Gibbs, M.C. Vieira and C.L.M. Silva. 1999. Thermal inactivation of Alicyclobacillus acidoterrestris spores under temperature, soluble solids and $\mathrm{pH}$ conditions for the design of fruit processes. Int. J. Food Microbiol. 51(2/3): 95-103.

Silva F.V.M., P. Gibbs and C.L.M. Silva. 2000. Establishing a new pasteurization criterion based on Alicyclobacillus acidoterrestris spores for shelf-stable high - acidic fruit products. Fruit Process. 10(4): 138-141.
Silva F.V.M., E.K. Tan and M. Farid. 2012. Bacterial spore inactivation at $45-65^{\circ} \mathrm{C}$ using high pressure processing: study of Alicyclobacillus acidoterrestris in orange juice. Food Microbiol. 32: 206-211. Skąpska S., B. Sokołowska, M. Fonberg-Broczek, J. Niezgoda, M. Chotkiewicz and A. Dekowska. 2012. Application of high pressure pasteurization to inactivate spores of Alicyclobacillus acidoterrestris in apple juice (in Polish). Żywność. Nauka. Technologia Jakość. 3(82): 187-196.

Sokołowska B., Ł. Łaniewska-Trokenheim, J. Niezgoda and M. Bytońska. 2008. Heat resistance of Alicyclobacillus acidoterrestris spores (in Polish). Przem. Ferm. Owoc. Warz. (12): 22-27.

Sokołowska B., J. Niezgoda, M. Bytońska and A. Frankiel. 2010. Biodiversity of Alicyclobacillus acidoterrestris strains (in Polish. Pr. Inst. Lab. Bad. Przem. Spoż. 65: 29-32.

Sokołowska B., S. Skąpska, M. Fonberg-Broczek, J. Niezgoda, M. Chotkiewicz, A. Dekowska and S. Rzoska. 2012. The combined effect of high pressure and nisin or lysosyme on the inactivation Alicyclobacillus acidoterrestris spores in apple juice. High Press. Res. 32(1): 119-127.

Sokołowska B., S. Skąpska, M. Fonberg-Broczek, J. Niezgoda, M. Chotkiewicz, A. Dekowska and S.J. Rzoska. 2013. Factors influencing the inactivation of Alicyclobacillus acidoterrestris spores exposed to high hydrostatic pressure in apple juice. High Press. Res. 33(1): 73-82.

Splittstoesser D.F., J.J. Churey and C.Y. Lee. 1994. Growth characteristic of aciduric sporeforming bacilli isolated from fruit juices. J. Food Protect. 57: 1080-1083.

Steyn C.E., M. Cameron and R.C. Witthuhn. 2011. Occurrence of Alicyclobacillus in the fruit processing environment - A review. Int J. Food Microbiol. 147: 1-11.

Vercammen A., B. Vivijs, I. Lurguin and C. Michiels. 2012. Germination and inactivation of Bacillus coagulans and Alicyclobacillus acidoterrestris spores by high hydrostatic pressure treatment in buffer and tomato sauce. Int. J. Food Microbiol. 152(3): 162-167.

Wang Y., T. Yue, Y. Yuan and Z. Gao. 2010. Isolation and identification of thermo-acidophilic bacteria from orchards in China. J. Food Protect. 73(2): 390-394.

Wuytac E.Y., S. Boven and C.W. Michiels. 1998. Comparative study of pressure-induced germination of Bacillus subtilis spores at low and high pressures. Appl. Environ. Microbiol. 64(9): 3220-3224.

Zhang J., T. Yue and Y. Yuan. 2013. Alicyclobacillus contamination in the production line of kiwi products in China. PLoS ONE 8(7); e 67704, doi:10.1371/journal.pone.0067704. 
